\title{
Vol. 30, No. 1
}

Spring 2019
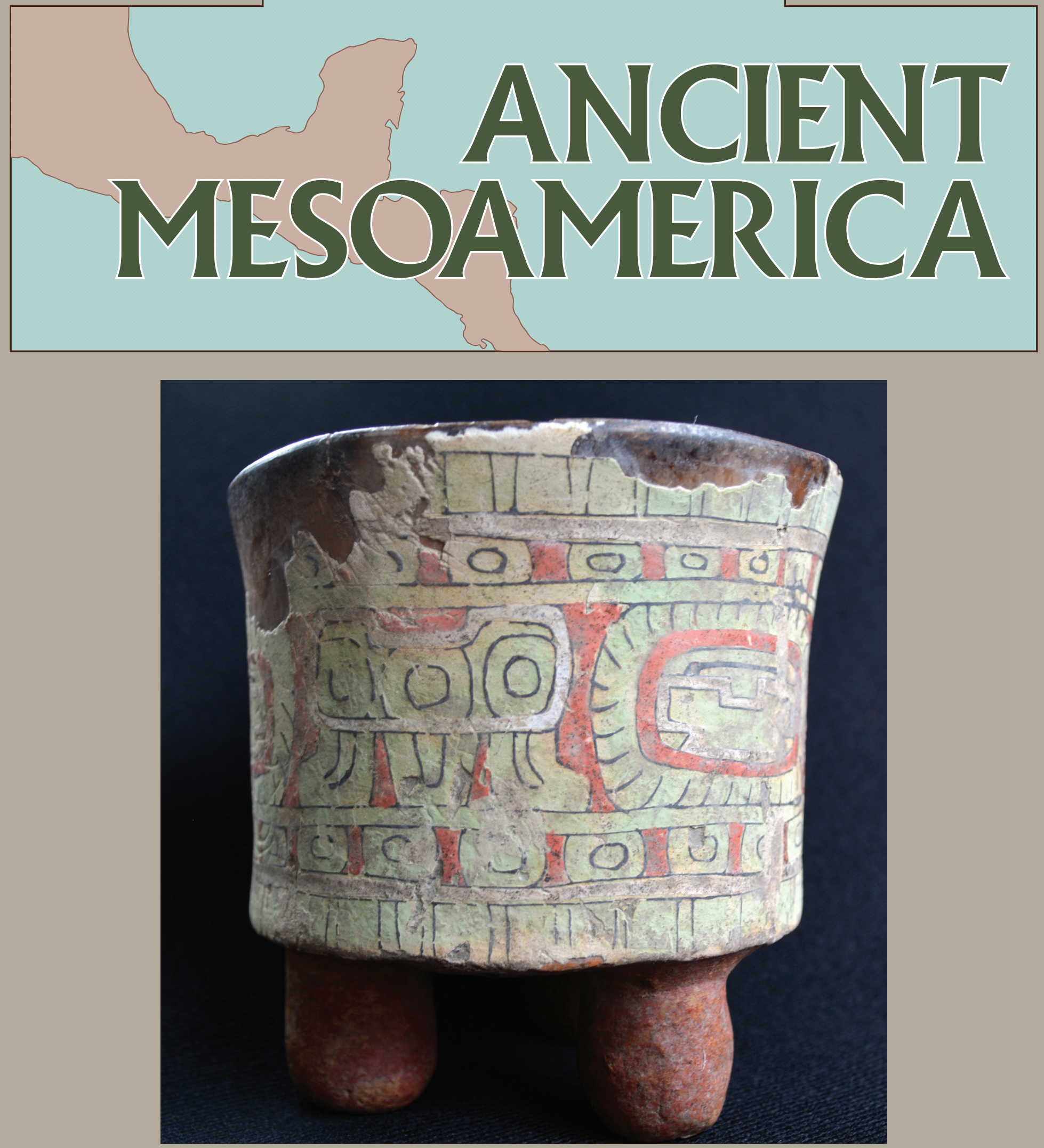


\title{
Ancient \\ Mesoamerica
}

\author{
Editor \\ William R. Fowler \\ Department of Anthropology \\ Vanderbilt University \\ Associate Editor: Nancy Gonlin, Bellevue College \\ Managing Editor: Bruce Bruschi \\ Editorial Assistant: Marlon V. Escamilla

\section{Editorial Board}

M. Charlotte Arnauld, CNRS-Université de Paris 1, Pantheón-Sorbonne Joseph W. Ball, San Diego State University Christopher S. Beekman, University of Colorado, Denver

Frances F. Berdan, California State University,

San Bernardino

Ronald L. Bishop, Smithsonian Institution

Nicholas P. Carter, Harvard University

Arlen Chase, University of Nevada, Las Vegas

Rafael Cobos, Universidad Autónoma de Yucatán

George L. Cowgill, Arizona State University

Arthur A. Demarest, Vanderbilt University

Nicholas P. Dunning, University of Cincinnati

\author{
Susan Toby Evans, Pennsylvania State University \\ Norman Hammond, Boston University \\ Kenneth G. Hirth, Pennsylvania State University \\ Stephen D. Houston, Brown University \\ Scott Hutson, University of Kentucky \\ Leonardo López Luján, Instituto Nacional de \\ Antropología e Historia, Mexico \\ Deborah L. Nichols, Dartmouth College \\ Jeffrey R. Parsons, University of Michigan \\ Payson D. Sheets, University of Colorado \\ Michael E. Smith, Arizona State University \\ Rebecca Storey, University of Houston \\ Karl Taube, University of California, Riverside
}

Ancient Mesoamerica is a triannual international forum for the method, theory, substance, and interpretation of Mesoamerican archaeology, art history, ethnohistory, historical linguistics, and related fields. The journal will publish original research papers, theoretical articles, and substantive reports of field research.

Editorial Offices

Vanderbilt University, Department of Anthropology, P.O. Box 128-B, Nashville, TN 37235, USA. Telephone: 615-343-9505. Fax: 615-343-0230. Email: ancientmeso@gmail.com.

Subscription Information

Ancient Mesoamerica (ISSN 0956-5361) is published three times a year (Spring, Summer, and Fall) by Cambridge University Press, One Liberty Plaza, 20th Floor, New York, NY 10006, USA. Periodicals postage paid at New York, NY 10006 and additional mailing offices. Annual subscription rates for Volume 30 (2019): Institutional subscription rate, print and electronic: US \$704 in the U.S.A., Canada, and Mexico; UK £399 elsewhere. Institutional subscription rate, electronic only: US \$586 in the U.S.A., Canada, and Mexico; UK $£ 334$ elsewhere. Institutional subscription rate, print only: US $\$ 682$ in the U.S.A., Canada, and Mexico; UK $£ 394$ elsewhere. Individual subscription rate, print only: US $\$ 137$ in the U.S.A., Canada, and Mexico; UK $£ 76$ elsewhere. POSTMASTER: Send all address changes to Journals Fulfillment Department, One Liberty Plaza, 20th Floor, New York, NY 10006, USA.

Indexing

This journal is covered in Thomson-Reuters Arts and Humanities Citation Index (ISI), Current Contents/Arts and Humanities, Anthropological Literature and Hispanic American Periodicals Index.

\section{Copyright (C) 2019 Cambridge University Press}

All rights reserved. No part of this publication may be reproduced, in any form or by any means, electronic, photocopying, or otherwise, without permission in writing from Cambridge University Press. General enquiries from the USA, Mexico, and Canada should be addressed to the New York office of Cambridge University Press, http:/ / www.cambridge.org/ us/information/ rights/ contacts/newyork.htm; general enquiries from elsewhere should be addressed to the Cambridge office, http://www.cambridge.org/us/information/rights/contacts/cambridge.htm; permission enquiries from Australia and New Zealand should be addressed to the Melbourne office, http://www.cambridge.org/us/information/ rights/contacts/australia.htm; enquiries regarding Spanish-language translation rights (only) should be addressed to the Madrid office, http:/ / www.cambridge.org/ us / information/ rights/ contacts/ madrid.htm.

Photocopying Information for users in the USA: Notwithstanding the above, the Item-Fee Code for this publication (0067-2378/16) indicates that copying for internal or personal use beyond that permitted by Sec. 107 or 108 of the U.S. Copyright Law is authorized for users duly registered with the Copyright Clearance Center (CCC) provided that the appropriate remittance is paid directly to: CCC, 222 Rosewood Drive, Danvers, MA 01923 U.S.A. Specific written permission must be obtained for all other copying; contact the nearest Cambridge University Press office.

Printed in the United States of America. 